\title{
Inclusion by Co-Production of Social Housing: The Slovak Experience
}

\author{
Maria Murray Svidronova, Beata Mikušová Meričková \\ Matej Bel University, Faculty of Economics, Slovakia \\ maria.murraysvidronova@umb.sk, beata.mikusovamerickova@umb.sk \\ https://orcid.org/0000-0002-4414-479X \\ https://orcid.org/0000-0002-3187-9201
}

\author{
Juraj Nemec \\ Masaryk University, Faculty of Economics and Administration, the Czech Republic \\ juraj.nemec@econ.muni.cz \\ https://orcid.org/0000-0002-5881-7422
}

Received: 12. 8. 2019

Accepted: 21. 10. 2019

\section{ABSTRACT}

The field of social housing is one of many subjected to the potentials of co-production. Specifically, the Sustainable Development Goals target 11.1 is "By 2030, ensure access for all to adequate, safe and affordable housing and basic services and upgrade slums". The current Slovak "State Housing Policy Concept to 2020", among others, defines specific objectives, e.g. increasing or at least maintaining the same share of public expenditure on housing, introducing a new housing allowance, and supporting the development of the non-profit sector in housing provision. The goal of this article is to investigate to what extent co-production - as joint working of the public, private for profit and private not-for profit sectors - has the capacity to address the gap in the provision of social housing in the Slovak Republic. Using the method of case study, the scale and forms of co-production in social housing are investigated and the key factors and barriers of co-production in this area are analysed. The authors suggest that co-production of social housing is the most efficient method of delivery of social housing, improves sustainability, and helps to include the beneficiaries into society. However, this approach requires extra energy from the stakeholders - especially from public officials - and is thus still rarely used in practice.

Keywords: co-production, social housing, social inclusion, case study, Slovakia

JEL: H44, L31, 018 


\section{Introduction}

The 2030 Agenda for Sustainable Development, adopted by all United Nations Member States in 2015, provides a blueprint for peace and prosperity for people and the planet, now and into the future (United Nations, 2015). The target 11.1 is "By 2030, ensure access for all to adequate, safe and affordable housing and basic services and upgrade slums". The simplified explanation of this target might mean that because housing services are public services, so the provision of housing improvement of housing situation should be the ultimate task for the state/self-governments.

However, such expectations cannot in truth become reality. The financial resources of the public sector are always limited and especially in developing countries there is no chance to finance all the costs of housing for the poor from public resources - and such an approach would not be effective for many reasons. Accodrding to Merickova et al. (2015), co-production represents one of the possible solutions - the provision of social housing in such an environment takes place through collaboration with different stakeholders. In this paper, we focus on the participation of different stakeholders in social housing provision at the level of local self-governments and on different forms of co-production, including the relevant drivers and barriers that account for the success or failure of co-production processes.

The goal of this article is to investigate to what extent the co-production (joint working of the public, private for profit and private not-for profit sectors) has the capacity to address the social housing gap in Slovakia (but also in other countries). The paper uses the case study approach as the main method, other methods used are qualitative analysis of relevant documents and databases and structured interviews with key stakeholders. The main sub-goals of this paper are to present the scale and forms of co-production in social housing area at the local level in Slovakia and to define the key factors and barriers of co-production in the social housing area. The paper follows the methodology and results from the LIPSE project (see for example Voorberg et al, 2014). The outline of the paper is as follows - the first part delivers the theoretical framework for co-production in social housing and characterise Slovak housing policy. The core part delivers two case studies about co-production of housing in Slovakia. The final part presents a qualitative analysis of the findings of the case studies and the lessons we can learn from these case studies.

\section{Co-production in social housing}

Participation of citizens, as final consumers of public services, has an irreplaceable role in the public service delivery process (Nemec et al., 2017) and has a great importance in success rate of this process (Fuglsang, 2008, Von Hippel, 2007). Before the New Public Management (NPM) era the idea was that public services should be dominantly produced and financed by the state (Samuelson, 1954) The NPM changes brought also the idea that public services delivery just means that the state is responsible for the availability of 
services, but the modes of production and financing are an open issue, determined by the proper local and time bounded response to questions "How can public services be produced?" and "How can public services be funded?" (Cullis and Jones, 1992 or Osborne and Gaebler, 1993): "public-private-civil sector mix, partnerships, competition and cooperation (Nemec, et al, 2015)". The governance era (Osborne and Brown, 2011) takes one step further - the process of delivery of public services is considered as 1) an open process, with the involvement of end-users in the design and development of goods and services (Chesbrough, 2003) and 2) a change of the relationships between the involved stakeholders (Voorberg, et al, 2014). One of the central elements in this concept is active participation of citizens and grass roots organisations in order to produce social outcomes that really matter, this is known as co-production/co-creation.

Co-production is regarded as a promising concept against austerity, ageing and the erosion of legitimacy of public institutions (Pestoff, 2014). During co-production, a citizen or other non-public actors may serve as "co-initiators", "co-designers" or "co-implementing subjects" (Voorberg et al, 2014). According to Sørensen and Torfing (2011) this kind of public innovation takes place through collaboration with different stakeholders. As a result, innovation is always relative to its context, which consists of elements such as 1) the political and administrative context, 2) the legal culture within the public sector, 3) state governance and civil service tradition and 4) resource allocation and resource dependency (Bekkers, et al, 2013). Key factors of co-production could be divided into being either on the organisation side or the citizen/non-state body side as shown by the Table 1 .

\section{Table 1: Drivers of co-production}

$\begin{array}{ll}\text { Key factors on the organisation side } & \text { Key factors on the citizen side } \\ \begin{array}{ll}\text { Compatibility of public organisations } \\ \text { with citizen participation }\end{array} & \begin{array}{l}\text { Citizen characteristics (skills, values, } \\ \text { education, willingness, etc.) }\end{array} \\ \begin{array}{ll}\text { Open attitude towards citizen } \\ \text { participation }\end{array} & \begin{array}{l}\text { Customer/citizen awareness/feeling of } \\ \text { ownership/ }\end{array} \\ \begin{array}{l}\text { Presence of clear incentives for co- } \\ \text { creation (win/win situation) }\end{array} & \text { Presence of social capital }\end{array}$

Source: created by the authors based on Bekkers et al., 2013.

Academic research recently started to deal with the issue of co-production especially in social housing. Adamson (2018) explored the extent to which United Kingdom tenants are engaged in a co-production of additional outcomes result of the co-production relationship. Gruber and Lang (in Adamson, 2018) provide an analysis of the institutional context of housing in Vienna and present the case studies of a particular collaborative housing model, inclu- 
ding short case studies of collaborative housing models relevant to the same local context.

Colasanti et al. (2018) analyse the evolution in the provision of public services delivery, with a specific focus on housing policies. They argue that rather than just assisting households with income levels falling below specific thresholds, social housing addresses the broader and more complex areas of vulnerability and that effective social housing projects require that beneficiaries contribute to the implementation of the project itself.

Our paper adds to this discussion - with the use of two case studies identified as examples of good practice where co-production in social housing is being applied.

\subsection{Slovak housing policy}

Since the establishment of an independent Slovak Republic in 1993, the issue of housing has been addressed in the state's housing policy. Since 1994, six social housing policy concepts have been developed, the latest is from $7 \mathrm{Ja}$ nuary 2015 for the period to 2020 (Špirková et al., 2009).

The current State Housing Policy Concept to 2020 (Koncepcia štátnej bytovej politiky do roku 2020: https://www.mindop.sk/ministerstvo-1/vystavba-5/ bytova-politika/) summarises recent developments in housing policy, outlines priorities for the coming period, and defines the tasks that ministries have to fulfil in order to meet the goals set. The main objective of the concept of state housing policy for 2015-2020 is the sustainable development of housing. Among other goals there is support of the development of the non-governmental organisations (NGOs) in housing services provision.

The direct rules for the provision of housing services are currently regulated in Slovakia by more legislative acts (especially the Act No. 443/2010 Coll. on subsidies for housing development and social housing, the Act No. 182/1993 Coll. on the ownership of flats and non-residential premises, the Act on the State Housing Development Fund No. 607/2003 Coll., and the Act on Housing Loans No. 90/2016 Coll.). Social housing legislation is quite fragmented, which complicates clarity and transparency (Murray Svidroňová et al, 2019).

The Act on subsidies for housing development and social housing defines social housing as "housing acquired through the use of public funds intended for the adequate and humane dwelling of persons who cannot obtain housing by their own actions and fulfil the conditions under this law. Social housing is also housing or accommodation funded by public funds and provided as part of care under specific regulations".

According to the latest Population and Housing Census 2011 (the next is planned for 2021), the total housing stock in Slovakia consisted of 1,994,897 housing units, of which 205,729 units were empty. The results of the census also showed that there were 370 housing units per 1,000 inhabitants, which is the second-lowest ratio in the European Union (EU) after Poland (www.sci- 
tanie2011.sk). In 2011, the total housing stock in Slovakia consisted of private housing $(90.5 \%), 6 \%$ were rented flats (out of which $3 \%$ were rented by municipalities and 3\% were rented privately), and 3.5\% were owned by housing cooperatives. These data clearly indicate a lack of social housing in Slovakia - most vulnerable groups of the population are not able to afford effective private housing solutions.

The Slovak Republic applies a dual model of delivery of social housing. Social housing is secured through public construction primarily provided by municipalities and from public funding - financed by state resources. The Municipal Act No. 369/1990 Coll., in paragraph 4, defines that municipalities are, among other duties, also responsible: “... to acquire and approve housing development programmes and to cooperate in creating suitable housing conditions in the municipality". Although social housing is the responsibility of the municipalities, they are unable to satisfy all existing needs because of a lack of finance (Murray Svidroňová et al., 2019).

In this situation, co-production, with involvement of several types of stakeholders is effective, but still a very rarely used solution in the Slovak conditions, especially when dealing with the marginalised Roma population. The United Nations Development Programme in cooperation with the Institute for Roma studies in Slovakia prepared an Atlas of marginalised Roma communities (2013) which estimates that in Slovakia in 2013 from the total number of 402,000 Roma more than $50 \%$ live in socially excluded communities. Moreover, 5,000 to 15,000 Roma families in Slovakia live in illegally built huts/ shacks, constructed from waste materials, without access to drinking water, electricity, heating and other services - in many cases more than 10 persons live in one small shack.

\section{Methods}

The goal of this paper is to investigate to what extent the co-production has the capacity to address the gap in provision of social housing in the Slovak Republic. Using the method of case study, the scale and forms of co-production in social housing are investigated, and the key factors and barriers of co-production in this area are analysed.

During our recent research, we were able to find only three clear examples of already realised social housing co-production-based activities: Kojatice, Rankovce and Svaty Anton. The last one is not analysed due to the death of the statutory representative of the organisation in a car accident in 2016, since then the organisation has ceased to operate. In the other two cases, we collected all existing secondary information and conducted twenty interviews with representatives of the organisations as well as the mayors and inhabitants of the municipalities.

Kojatice is a small village in the east of Slovakia with an important proportion of Roma minority, living in very poor housing conditions (15 or 20 persons living in one small, dilapidated house without electricity, water and sewerage). 
The goal of this co-production initiative was to build social houses for marginalised groups of citizens. No specific event sparked this initiative; it was just the idea of a small group of people volunteering in an NGO "People in Need" how to respond to the long-term need to support a vulnerable group of citizens.

The preparation for the social housing project started in 2005 - it was very important to build up relationships with social workers and subsequently through them with the Roma citizens because of the high level of distrust between Roma citizens and the majority of the population. The project itself started in 2011; the first houses were finished in summer 2013, the final number of finished houses was eight (Nemec \& Svidroňová, 2015).

The main principle of the project is an individual approach and personal commitment of initiators and beneficiaries: young volunteering architects in communication with Roma citizens created plans and technical documentation for the construction of houses based on the Roma requirements and ideas. Within the first stage of the programme the workshop took place, where 16 volunteer architects and students of architecture prepared feasibility studies on how to improve the housing conditions of Roma families. New structures and refurbishments were proposed according to the needs and wishes of the participating families. The architects worked in teams directly with the clients and the results were presented to the residents of the village during the final presentation (People in Need, http://www.kojatice.sk/uploads/file/ Komunitne\%20centrum/HousingProgram_A\&V.pdf).

Those Roma, who had decided to participate, were trained in construction work to be able to participate directly in the construction of their houses. Roma were involved also in financing - first, for one year they saved money in a joint fund (each family approx. 2,000€). After this, in the following years they were involved in a microcredit system - this system provided all of them an interest-free loan between 1,000-1,400€ to support financing of construction of the houses (this loan is paid back monthly in 20 or $30 €$ instalments). In total, the financial contribution of participating Roma was approx. 3,300 €. Total cost of one house is around 10,000 € of which two thirds are funded by NGOs and municipality (municipality provides land and only very limited direct funding) and the rest of the sum is paid by the Roma citizens. A specific training on financial literacy was offered to the Roma citizens, to help them to manage their finance, to be able to pay off the loans (Nemec \& Svidroňová, 2015).

The main initiator of this project was the Slovak citizen association People in Need (www.peopleinneed.sk), which deals with social cohesion, humanitarian aid and human rights protection. Some volunteer members of this organisation studied architecture and they came up with the idea of building social houses for a marginalised group of citizens. These architecture students have the obligation to deliver practical work as a part of their final exams and they decided to go for the idea of helping to improve the poor living standard in the huts of Roma citizens in the east of Slovakia. The other core stakeholders of the co-production initiative were the municipality of Kojatice and its mayor and other NGOs, namely ETP Slovakia and Pontis Foundation. The mu- 
nicipality provided very limited funding but they gave the land for the housing (otherwise, building the houses on the plots of land would have been illegal). The NGOs ETP and Pontis Foundation helped with funding and with setting up the micro-loan programme (know-how of the ETP organisation which is an initiator of co-production in the second analysed case).

The Rankovce case is very similar to Kojatice, but slightly different. Rankovce is also a small village in the east of Slovakia with an important proportion of Roma minority, living in small, dilapidated houses without electricity, water and sewerage (Nemec \& Svidroňová, 2015).

This initiative of building social houses for marginalised groups of citizens was started by the NGO ETP Slovakia, which has been operating in Slovakia since 1992. Similar to the NGO People in Need (Kojatice case) ETP Slovakia also works with disadvantaged groups, especially from segregated Roma communities, as well as refugees. However, the start of this initiative was "more organised", because of being directly connected to the NGO's mission. The first specific enabling factor in this case is the fact that one of ETP Slovakia's programmes is the development of housing for those families living in unsatisfactory conditions and to improve the quality and conditions of housing by themselves with the help of a construction "teacher". The second specific enabling factor is the fact that ETP Slovakia runs a community centre in Rankovce (Murray Svidroňová et al, 2019).

Since January 2013, ETP Slovakia, in cooperation with local self-government, field social workers and the local association "For a Better Life", have supported sixteen Rankovce families (the number of participating families increased to 30 during the life of the programme) in a similar way to that described in the Kojatice case. ETP Slovakia provided coordination, construction plans and its Savings and Micro-Loan Programme. Roma participated via self-construction and finance. The municipality provided cheap land and general support to the project. The total cost of one house is around $12,000 €$, of which onethird is funded by NGOs and sponsors (the main sponsor was the company Holcim providing in-kind material for the construction), and the rest of the sum is paid by the Roma citizens. The saving programme helps them to save around $400 €$ and the microloan programme provides an interest-free loan of around 6,000 $€$ to finance the building of the houses. As a bonus for timely payment of the instalments, they can get up to 1,200 $€$ bonus from the NGO. The project received the European Commission Award for Best Projects of Building a Social Society in 2014 ((Nemec \& Svidroňová, 2015; Murray Svidroňová et al, 2019).

\section{Results}

To be able to evaluate the core aspects of two successful social housing projects in Slovakia, we organised more than twenty interviews with all stakeholder participants (Roma, inhabitants of villages, municipal mayors and NGO representatives) and academic experts. The aim was to better understand the 
factors and barriers, intervention logics (see Voorberg et al, 2015) and social impacts of this initiative

\subsection{Main project drivers and realisation barriers}

According to the results from the interviews, the core driver for both cases was the fact that innovative and comprehensive solutions to housing problems by combining education, employment, financial inclusion and housing construction was proposed - this fact motivated all involved stakeholders to support the initiative.

Another core driver is the availability of needed financial resources. The main enabler was the existence of the ETP Slovakia Savings and Micro-Loan Programme, providing the chance for Roma to save and to borrow under specific financial conditions.

In the case of Rankovce, the fact that ETP Slovakia was already running a community centre in the village before the project started was a critical success factor - the co-operation of all actors was significantly simpler (higher level of trust) and the chance to get sponsors was higher.

The biggest barrier in both projects was the distrust of Roma to the proposal. In the Kojatice case, this issue was solved with the help of social workers who had been working with these people for a longer time and also thanks to the attitudes of participating students of architecture. The social workers understand the mentality of Roma and their assistance was a big help. Many visits and special communication skills were required to earn the trust of the Roma. Students consulted with Roma building plans and tried to motivate them to co-product for their future better life. In Rankovce, the main initiator ETP Slovakia was much better known from the beginning thanks to the local community centre.

A specific barrier was the problems in obtaining building permits. Protracted dialogues with the Building Office, with the help of other partners (especially the mayor), were necessary to solve this issue in both cases.

In Kojatice the initial dissatisfaction in particular on the part of the local non-Roma community with the idea of building the social houses represented another specific barrier. Some Kojatice citizens were not happy that the mayor was ready to work with and to help to only a part of the community. This barrier was solved via intensive dialogue and promotion of the co-production initiative.

The specific barrier for both projects was the need to finance the Savings and Micro-Loan Programme managed by ETP Slovakia (involved in financing of both cases). Because this programme provided interest free loans, it cannot be self-financing and involvement of donors is necessary. 


\subsection{Intervention logics}

Based on the analysis of investigated cases we first summarise the role of different actors who participated in the selected cases (Tables 2 and 3). We describe their role in three stages based on three types of co-production: initiatior, designer and implementer.

Table 2: Role of actors: Kojatice

\begin{tabular}{|rccc|}
\hline $\begin{array}{c}\text { Project } \\
\text { initiation }\end{array}$ & $\begin{array}{c}\text { Project } \\
\text { design }\end{array}$ & $\begin{array}{c}\text { Project } \\
\text { implementation }\end{array}$ \\
\hline Non-organised citizen & Yes & Yes & Yes \\
NGO & Yes & Yes & Yes \\
\hline Private sector & No & No & No \\
Municipality & No & Partly & Yes
\end{tabular}

Source: authors.

Table 3: Role of actors: Rankovce

\begin{tabular}{|rccc|}
$\begin{array}{c}\text { Project } \\
\text { initiation }\end{array}$ & $\begin{array}{c}\text { Project } \\
\text { design }\end{array}$ & $\begin{array}{c}\text { Project } \\
\text { implementation }\end{array}$ \\
\hline Non-organised citizen & Yes & Yes & Yes \\
NGO & Yes & Yes & Yes \\
Private sector & No & No & Partly \\
Municipality & Partly & Yes & Yes
\end{tabular}

Source: authors based on Merickova et al., 2015.

\subsection{Social impacts}

The fact that providing social housing is the core inclusion factor for marginalised groups is already confirmed by academic studies and practical experiments (first well-known project of this type started in Los Angeles in 1988) - available affordable quality housing means better health, increased responsibility, improves children's school attendance and new working experience improves the chance for employment (Nemec \& Svidroňová, 2015). However, our cases represent "one step-forward" - social housing is provided via co-production. The responses from interviews clearly show that this approach delivers multiplicative effects. 
The evaluated projects represent cases of improved effectiveness, efficiency, equity, fairness, but also public trust and public participation. The standard of living improved as the direct project output, and the style of living of Roma changed as the long-term outcome. A sense of responsibility and ownership has been created, changing future Roma lives. The statements of interviewees support these observed impacts:

"I believe that this project is a clear signal that it is necessary to take a chance and seize the opportunities, to actively participate. For the coexistence of Roma and non-Roma communities the participation of Roma in the construction work was very beneficial."

Former student - one of the project initiators, Rankovce case

"Better hygiene thanks to running water, not to be ashamed of their homes, better conditions for studying and working - that all helps to integrate Roma into society."

Former student - one of the project initiators, Rankovce case

"The acceptable housing, working experience when helping to build the house and financial responsibility for part of its financing are impetuses for positive changes of the Roma citizens' life style."

Former student - one of the project initiators, Rankovce case

"Specific project outcomes are improved public space, improved image of the municipality and improved social relations in the region and new forms of co-operation between different NGOs, new ways of involving foundations which helps them to improve their activities in the field of social cohesion, humanitarian aid and human rights protection."

Academic expert, Kojatice case

"For local government the initiative brought solutions to housing problems for its citizens."

Head of the local council, Kojatice case

\section{Discussion}

In general, the Sovak public sector has a rather low interest in innovations in public services provision (e.g. Murgasova, 2014, Kožiak \&Suchý, 2014). In such situations the third sector (civic sector, NGOs or grass root organisations) is more often the source for social innovations (Škarabelová \& Vaceková, 2013), especially in rural areas (Valentinov \& Vaceková, 2015).

In this paper, we discussed co-production-based innovations in the sector of welfare, namely social housing, in Slovakia. In the cases analysed, cooperation between the third and the public sector was demonstrated in the case of social housing in the villages of Rankovce and Kojatice. NGOs provide micro-loans as well as financial and social education for the population. The involvement of the Roma themselves in sharing the financial costs of construction as well as the building work creates a sense of co-ownership, and these houses are not 
as quickly destroyed as is the case with allocated state-owned flats (Murray Svidroňová et al. 2019). We consider these initiatives a good basis on which to build and develop the provision of housing services by the third sector through the implementation of properly selected recommendations.

Taking all the above into account, the obvious question arises - "Why the number of similar activities is really limited in Slovakia (and in similar countries, too)? The response should be based on the following trade-off. Co-productive housing provision is on the one hand more efficient (decreases costs), delivers more sustainable results (the notion of public value becomes more tangible with co-production - Mikušová Meričková and Svidroňová, 2014: self-help builders are seen to develop a sense of co-ownership of the home, and, after repaying the micro-loan, they acquire the house as their own property) and supports inclusion of marginalised groups. However, co-productive housing provision also needs extra effort from all the stakeholders. Such efforts are expected on the part of participating NGOs, sponsors or volunteers; however, they also represent extra workload for public officials involved (building social housing with support from state grants and allocating flats is a simpler approach compared to co-production). With this, the core enabler is local will - especially the attitudes of the local mayor who represents the municipality. This statement can be very simply documented - together with the successful experiment in Rankovce ETP Slovakia tried to realise the same activity in other Slovak municipalities. However, that attempt failed, simply because the municipal leaderships were not ready to co-operate.

\section{Conclusion}

Based on our analysis of the social housing cases, it is clear that all respondents are positive about evaluation of the outcomes. The main outcome is a better standard of living of the Roma citizens (as Nemec \& Svidroňová, 2015, pointed out: learning active participation, developing manual skills by building their houses and basic education in financial literacy). Also the municipalities feel, that the co-production process improves delivery of public service of housing for which the municipality is responsible. Analysed cases of social housing projects help to decrease costs and thus have a minimal burden to the public budget. Among other outcomes there are improved public spaces (newly built houses look much better than the huts), better social relations in the municipalities and new forms of co-operation between various non-governmental organisations and other key players (i.e. building of social capital).

Improved self-responsibility of the Roma citizens is the critical issue - involved Roma citizens were educated in financial literacy and gained other skills through self-help home construction. In the case of Rankovce, this involvement of Roma helped eleven of them to find a permanent job thanks to the skills they acquired in the self-construction activities. This is clear evidence of the fact that co-production in social housing has a large potential to support inclusion of marginalised groups into society. 
At the end of this paper we need to mention that the validity of an in-depth, but small-scale study may be limited. Despite this, the results presented in in this study should assist a multi-level approach analysis focused on interaction between the individuals and the organisations. Future research on co-production should also focus on comparative analysis between sectors and/or countries. This paper serves as a basis for a deeper analysis of provision of social housing services by the NCOs, including the use of quantitative methods such as value for money or cost benefit analysis, to analyse a higher efficiency of social housing provided by the NGOs.

For policy makers the paper proposes that because social housing target groups normally also need other types of services (such as lessons on how to find a job, how to manage finances, and in some cases lessons on basic hygienic habits and how to take care of the allocated housing) these services should be set up and offered in all cases where social housing is provided. Such an approach also ensures regular monitoring of the situation of social housing and helps with social inclusion of the Roma citizens (Murray Svidroňová, et al., 2017; Suchalová \& Staroňová, 2010).

\section{Acknowledgement}

The research is supported by the Czech Grant Agency GACR under contract No. GA19-06020S Foundation „Alternative service delivery arrangements". 


\section{References}

Act no. 182/1993 Coll. on the ownership of flats and non-residential premises Act no. 443/2010 Coll. on subsidies for housing development and social housing Act no. 607/2003 Coll. on The on the State Housing Development

Act no. 90/2016 Coll. on housing loans

Adamson, D. (2018). Two modes of co-production in social housing. Comparing UK and Australian experience. In G. Van Bortel, V. Gruis, J. Nieuwenhuijzen, B. Pluijmers, eds., Affordable Housing Governance and Finance. Innovations, partnerships and comparative perspectives. London: Routledge, pp. 143-162.

United Nations. (2015). Agenda2030. At <https://sustainabledevelopment. un.org/post2015/transformingourworld/>, accessed 1 May 2019.

Bekkers, V.J.J.M., Tummers, L.G. and Voorberg, W.H. (2013). From public innovation to social innovation in the public sector: A literature review of relevant drivers and barriers. Rotterdam: Erasmus University Rotterdam.

Chesbrough, H. (2003). The era of open innovation. MIT Sloan Management Review, 44(3), pp. 35-42.

Colasanti, N., Frondizi, R. and Meneguzzo, M. (2018), "The Co-production of Housing Policies: Social Housing and Community Land Trust", Cross-Sectoral Relations in the Delivery of Public Services (Studies in Public and Non-Profit Governance, Vol. 6), Emerald Publishing Limited, pp. 155-176.

Cullis, J., Jones, P. and Jones, P. R. (2009). Public finance and public choice: analytical perspectives. Oxford University Press.

Fuglsang, L. (2008). Capturing the benefits of open innovation in public innovation: a case study. International Journal of Services Technology and Management, 9(3-4), pp. 234-248.

Kožiak, R. and Suchý, M. (2014). Klaster ako inovatívny prvok podpory miestneho a regionálneho rozvoja v oblasti obnovitel'ných zdrojov energie. In XVII. International Colloquium on Regional Sciences, conference proceedings, pp. 120-126. Brno: Masaryk University.

Merickova, B.M., Nemec, J. and Svidronova, M. (2015). Co-creation in local public services delivery innovation: Slovak experience. Lex Localis, 13(3), pp. 521535.

Mikušová Meričková, B., Svidroňová, M. (2014). Co-creation in public services: an alternative public service delivery arrangement. In XIX. International conference "Theoretical and Practical Aspects of Public Finance" conference proceedings. Prague: University of Economics.

Murgasova, J. (2014). Regionálne dimenzie inovačných procesov. (Regional dimensions of innovation processes). [Dissertation thesis]. Banská Bystrica: Faculty of Economics, Matej Bel University.

Murray Svidroňová, M. et al. (2017). Social Housing Provided by the Third Sector: The Slovak Experience. Critical Housing Analysis, 4(1), pp. 67-75.

Murray Svidroňová, M., Kuvikova, H., Merickova, B.M. and Nemec, J. (2019). Can Social Innovations in Housing Save Public Money? The Case of Slovakia. International Journal of Public Administration, pp.1-10.

Nemec, J., Mikušová Meričková, B., Murray Svidroňová, M. and Klimovský, D. (2017). Co-Creation as a Social Innovation in Delivery of Public Services at Local Government Level: The Slovak Experience. In Handbook of research on sub-national governance and development (pp. 281-303). IGI Global. 
Nemec, J. and Svidroňová, M. (2015). Co-creation in housing services: Kojatice case in Slovakia. In XVII. International colloquium on regional sciences, pp. 413-420. Brno: Masaryk University.

Osborne, D. and Gaebler, T. (1993). Reinventing government: How the entrepreneurial spirit is transforming the public sector. At <http:// government.cce.cornell.edu/doc/summary.asp?id=osborne1992\#market>, accessed 1 May 2019.

Osborne, S.P. and Brown, L. (2011). Innovation, public policy and public services delivery in the UK. The word that would be king? Public administration, 89(4), pp. 1335-1350.

People in Need, (n.d). Housing Program: achievements and visions. At <http:// www.kojatice.sk/uploads/file/Komunitne\%20centrum/HousingProgram_A\&V. $p d f>$, accessed 1 May 2019.

Pestoff, V. (2014). Collective action and the sustainability of co-production. Public Management Review, 16(3), pp. 383-401.

Population and Housing Census 2011. At <http://scitanie2011.sk>, accessed 1 May 2019.

Samuelson, P. A. (1954). The Pure Theory of Public Expenditure. Review of Economics and Statistics, 36(4), pp. 387-389.

Škarabelová, S. and Vaceková, G. (2013). The role of third sector organizations in rural development. In XVI. Mezinárodní kolokvium o regionálních vědách, conference proceedings, pp. 549-556. Brno: Masaryk University.

Sørensen, E. and Torfing, J. (2011). Enhancing collaborative innovation in the public sector. Administration \& Society, 43(8), pp. 842-868.

Špirková, D. et al. (2009). Bývanie a bytová politika. Vývoj, determinanty rozvoja bývania a nové prístupy v nájomnej politike na Slovensku. Bratislava: Slovak Technical University.

State Housing Policy Concept to 2020. (n.d.). At <http://www.telecom.gov.sk/ index/index.php?ids=81554>, accessed 1 May 2019.

Suchalová, A. and Staroňová, K. (2010). Mapping of social housing in the Slovak municipalities. Bratislava: Institute of Public Policy.

The Municipal Act No. 369/1990 Coll.

Valentinov, V. and Vaceková, G. (2015). Sustainability of rural nonprofit organizations: Czech Republic and beyond. Sustainability, 7(8), pp. 98909906.

Von Hippel, E. (2007). Horizontal innovation networks - by and for users. Industrial and Corporate Change, 16(2), pp. 1-23.

Voorberg, W.H., Bekkers, V.J.J.M. and Tummers, L.G. (2014). Co-creation in social innovation: A comparative case-study on the influential factors and outcomes of co-creation. IRSPM - conference, Ottawa Canada 9 April - 11 April 2014.

Voorberg, W.H., Bekkers, V.J.J.M. and Tummers, L.G. (2015). 'A systematic review of co-creation and co-production: Embarking on the social innovation journey.' Public Management Review (17) 9, pp. 1333-1357. 